Recebido em 1/12/2015 e aprovado em 8/7/2016

\title{
AS PAISAGENS DO FILME O ABISMO PRATEADO (KARIM AIINOUZ; 2013)
}

\section{THE LANDSCAPES OF THE MOVIE O ABISMO PRATEADO (KARIM AIINOUZ; 2013)}

Aline $\mathrm{Vaz}^{1}$

\section{Resumo}

O trabalho busca discutir a relação das personagens com as paisagens da cidade fílmica de $\bigcirc$ Abismo Prateado (Karim Aïnouz; 2013), um híbrido composto por edifícios, areia e mar. As personagens são expostas às imagens da natureza (praia) e da intervenção urbana (moradias), enclausurando Violeta (Alessandra Negrini) no não-lugar, uma personagem de estrada, que nos termos de Marc Augé (2007) ocupa lugares de passagem. Investiga-se como as paisagens, enquadradas pela tela cinematográfica, criam metáforas e interações com as personagens entre a procura da razão, o concreto das edificações humanas e o mar de emoções, a praia.

Palavras-chave: Cinema brasileiro; Paisagens; Não-Lugar.

\section{Abstract}

The work discusses the relationship of the characters with the landscapes of filmic city of $O$ Abismo Prateado (Karim Aïnouz; 2013), a hybrid composed of buildings, sand and sea. The characters are exposed images of nature (beach) and urban intervention (housings), enclosing Violet (Alessandra Negrini) in the non-place, a road character, that under Marc Augé (2007) deals with passing places. Investigating as landscapes framed by the motion picture screen create metaphors and interactions with the characters between the demand of reason, the concrete human buildings and the sea of emotions, the beach.

Keywords: Brazilian Cinema; Landscapes; Non-Place.

\footnotetext{
1 Mestranda em Comunicação e Linguagens, pela Universidade Tuiuti do Paraná e pesquisadora nos GPs Desdobramentos Simbólicos do Espaço Urbano em Narrativas Audiovisuais (PPGCOM - UTP) e CINECRIARE (UNESPAR/FAP). Bolsista CAPES. Email: alinevaz88@hotmail.com
} 
VAZ, Aline. As paisagens do filme O Abismo Prateado (Karim Aïnourz). Domínios da Imagem, Londrina, v. 10, n. 19, p. 156-171, jul./dez. 2016.

ISSN 2237-9126

\section{Introdução}

Rob Shields (apud MACHADO, 2000, p. 216) definiu a praia como um espaço "liminar" entre ordem e transgressão. Em tempos líquidos, areia e mar são invadidos por prédios e a correria da rotina burocrática. Nem todos ao redor da praia são turistas, nem todos podem passar os dias tomando banho de sol e mar. Aqueles que moram nos prédios, cumprem seus destinos diários que as ondas não podem levar, "a paisagem, efêmera, se dissolve em concreto" (LAMPERT, 2013, p. 52).

Os lugares são textos, pois produzem significados estabelecidos pelos contextos que operam e a experiência daquele que lê esse textolugar.

Semioticamente, a praia pode ser lida como um texto, ou seja, como uma construção significativa de potenciais significados que operam a vários níveis (...) Como nos outros textos, esses significados são, em parte, determinados pela estrutura do próprio texto, em parte pelas características sociais e práticas discursivas do leitor (FISKE, 1989, apud MACHADO, 2000, p. 202).

Segundo Helena Machado (2000, p. 212) a praia tem um significado terapêutico e outro significado lúdico, o primeiro surge associado aos elementos "frios" e o segundo corresponde a uma valorização dos elementos "quentes".

A praia do filme brasileiro, O Abismo Prateado (Karim Aïnouz; 2013), é uma praia em crise, não é terapêutica, nem lúdica. Ela é fria, mas não cumpre o processo de higienização do corpo da praia terapêutica, que, como pressupõe Machado (2000, p. 211), "só pode surtir efeitos fora do meio urbano e industrial, nomeadamente à beira-mar". Na praia lúdica valoriza-se o olhar e ser olhado, que na correria da rotina dos moradores da praia fílmica em análise, não constitui um olhar contemplativo, mas sim uma visão distraída. A praia é invadida por edificações, pelo movimento das tarefas diárias em busca de metas, "a 
VAZ, Aline. As paisagens do filme O Abismo Prateado (Karim Aïnourz). Domínios da Imagem, Londrina, v. 10, n. 19, p. 156-171, jul./dez. 2016.

ISSN 2237-9126

palavra progresso evoca uma insônia povoada por pesadelos: "ser deixado para trás", perder o trem, ser atirado para fora do veículo por um movimento brusco" (BAUMAN, 2009, p. 53).

"As metáforas que propõem a lente da câmera como uma espécie de olho de um observador astuto" (XAVIER, 2005, p. 22), permitem analisar como o cinema se comunica com aspectos de uma dita realidade representada na tela. Por meio de frames do filme, o estudo se dá nos termos em que "saber como o filme nos diz alguma coisa é mais uma maneira de compreender melhor o que ele quer nos dizer" (BAZIN, 1989, p. 72). Investiga-se, assim, como mar e paisagem urbana se comunicam, como o sujeito lida com as paisagens internas e externas que, grosso modo, compõem uma relação híbrida de sujeito e lugar.

\section{As Paisagens de Djalma}

O sujeito fragmentado, que segundo Stuart Hall (2006) abriga várias identidades, também abriga (e habita) vários lugares. Neste contexto, um novo lugar vem ganhando moradores - a praia urbana - de um lado a natureza e de outro a intervenção humana.

"O que é uma praia urbana? Propõe-se como definição, que as praias urbanas sejam aquelas que bordejam cidades, bairros ou balneários consolidados de diversos níveis de desenvolvimento (Smith, 1991). Ou seja, são praias adjacentes a conjuntos de estruturas e equipamentos urbanos como amuradas, calçadões, equipamentos esportivos e de lazer, pistas de rolamento, calçadas, jardins e prédios, (públicos ou privados) que de alguma forma se juntam ao ambiente praial para compor a paisagem, transformando-a em um "espaço produzido", ou seja, em uma "natureza social" (Coriolano, 2007). Sendo assim, são ambientes sob ocupação e influência humana direta, e pesadamente utilizados, tanto pelas populações locais como por visitantes (COSTA, 2008, p. 234). 
Nos primeiros minutos do filme $O$ Abismo Prateado, conhecemos a personagem que mergulha no mar e em seguida caminha pela cidade. Ela deixa o mar e dá as costas para as ondas, olha para o seu próximo destino - a cidade. O enquadramento não permite que a olhemos, vemos apenas luzes em meio à escuridão da praia, luzes que não clareiam a visão, mas desfocam o olhar (Figura 1).

Figura 1 - Frame do filme O Abismo Prateado

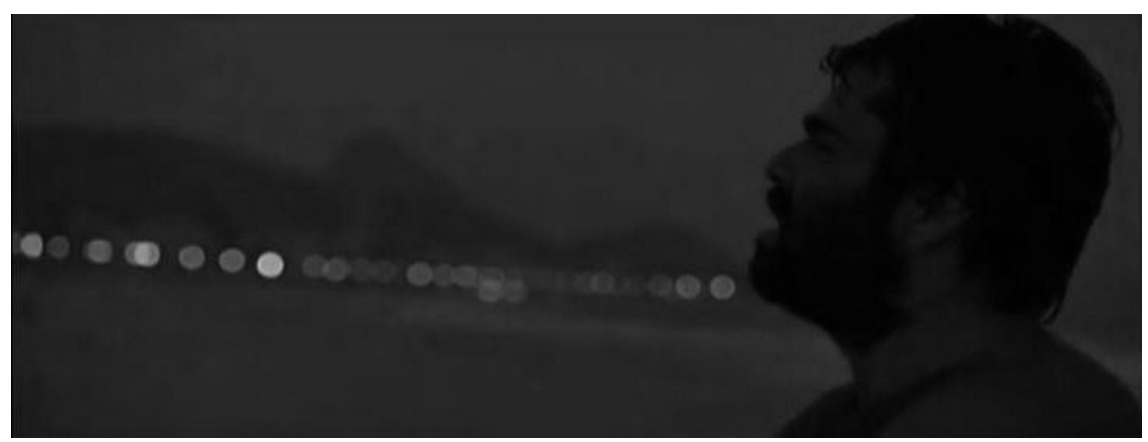

Djalma olha para a cidade: é preciso voltar para a rotina urbana.

Djalma (Otto Jr.), trajando roupa de banho, caminha na rua tomada por transeuntes. Entre moradores apressados em suas rotinas, que nada tem a ver com um banho de mar, a personagem não pertence ao lugar pelo qual caminha, ela está desconfortável, é grande demais para poder habitar a praia que é habitada pela cidade (Figura 2).

Figura 2 - Frame do filme O Abismo Prateado

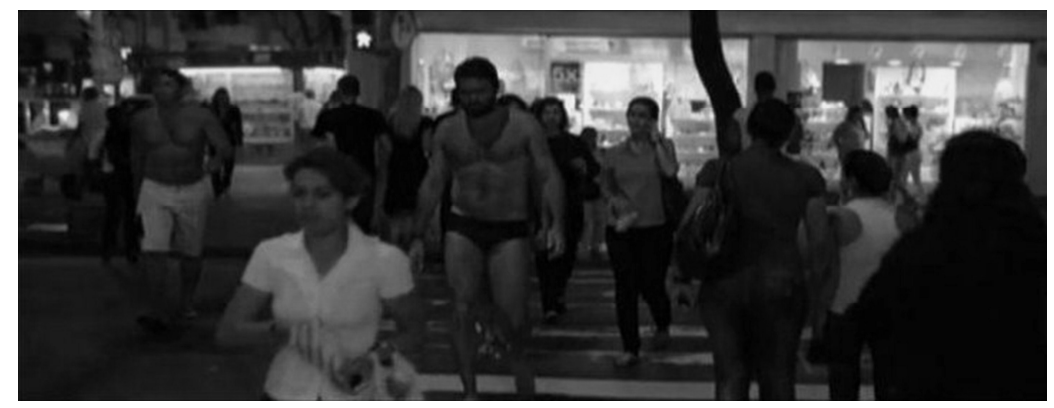

Djalma é grande demais para a cidade, não pertence ao contexto que se impõe. 
VAZ, Aline. As paisagens do filme $O$ Abismo Prateado (Karim Aïnourz). Domínios da Imagem, Londrina, v. 10, n. 19, p. 156-171, jul./dez. 2016.

ISSN 2237-9126

O cenário externo do filme é a cidade fílmica do Rio de Janeiro, mas poderia ser qualquer outra praia urbana. As praias de Pernambuco vêm sido invadidas por prédios, alguns filmes já retratam a nova paisagem, como O Som ao Redor (Kleber Mendonça Filho; 2012), que ao transpor a estética da insegurança, enclausura a visão que deveria dar para o mar. O filme Medianeras: Buenos Aires na Era do Amor Virtual (Gustavo Taretto; 2011), ao retratar uma Buenos Aires fílmica que dá as costas ao mar, representa uma cidade que dá as costas às suas personagens. Percebe-se uma invasão globalizada da urbanização arquitetônica.

Na Espanha, em muitos locais, a urbanização não deixou espaço suficiente para a dinâmica costeira, acarretando prejuízos ambientais, comerciais e recreacionais (Doody, 2001). Em Barcelona, por exemplo, alguns trechos de praias tornaram-se inacessíveis ao público devido à existência de uma grande quantidade de infraestruturas privadas em decorrência do crescimento populacional e do turismo a partir de 1960 (Breton et al., 1996). Na Itália, cerca de $1100 \mathrm{~km}$ da costa, de um total de $7500 \mathrm{~km}$, estão em erosão devido a vários fatores nos quais se inclui a construção indevida de obras (Viles \& Spencer, 1995). Nos Estados Unidos, a principal ameaça às praias é a presença de residências, estradas e outras construções que bloqueiam o suprimento de areia ao longo da praia (Daniel, 2001) (ARAÚJO, 2007, p. 102).

No lugar em que o mar não é contemplativo ele é o caos: os turistas flanam os lugares; moradores estão sempre a caminho percorrem espaços para chegar aos destinos burocráticos, em que tarefas do cotidiano devem ser cumpridas. A personagem que aparece dentro do mar está dentro desse caos, ela não pertence àquele lugar, assim como o mar não pertence à rotina dos moradores dos edifícios. A 
VAZ, Aline. As paisagens do filme O Abismo Prateado (Karim Aïnourz). Domínios da Imagem, Londrina, v. 10, n. 19, p. 156-171, jul./dez. 2016.

ISSN 2237-9126

praia é o não-lugar, em que a relação de passagem "não cria nem identidade singular nem relação, mas sim solidão e similitude" (AUGÉ, 2007, p. 94).

Essa personagem que se joga ao mar em busca de ar é um homem grande, grande demais para a praia urbana, é preciso fugir da maldição do tédio, pois "se nossas relações ainda não são aquelas que gostaríamos de desenvolver; [...] tendemos a imaginar maquinações hostis, complôs, conspirações de um inimigo que se encontra em nossa porta ou embaixo de nossa cama" (BAUMAN, 2009, p. 15).

A personagem foge, cumpre a sua passagem pelo espaço de não-pertencimento. Na cidade-ciborgue, conceituada por André Lemos (2007), como um híbrido composto por redes sociais e infraestruturas físicas, Violeta (Alessandra Negrini) descobre a partida do marido mediada por uma mensagem de voz no celular:

Violeta, meu amor, eu to indo embora, eu não vou voltar, eu vou pra Porto Alegre, depois eu vou pra Patagonia, não sei. Eu não vou voltar. A verdade é que eu to sem ar, to sufocando do teu lado. Não me chama de volta, senão eu volto e a gente afunda junto. Eu não te amo mais. Eu não te amo mais. Violeta, eu não te amo mais (Abismo Prateado, 2013).

Abre-se o abismo.

\section{As Paisagens de Violeta}

Pierre Bourdieu (1977, p. 03) lembra que a "percepção do mundo natural não tem, em si, nada de natural". Georges Didi-Huberman (1998) suscita o elo entre olhante e olhado. Diante dos pressupostos conclui-se que a percepção do olhante determinará o olhar do olhado e viceversa. Violeta é uma mulher com a visão alterada pelo trauma do abandono. A personagem vaga pela cidade, tentando sair de um lugar 
VAZ, Aline. As paisagens do filme $O$ Abismo Prateado (Karim Aïnourz). Domínios da Imagem, Londrina, v. 10, n. 19, p. 156-171, jul./dez. 2016.

ISSN 2237-9126

que a encurrala, entre a praia e as edificações, entre o instinto natural, o amor que, como as ondas, é incontrolável, e a razão, uma busca por respostas que não podem habitar o oceano das emoções - prédios não habitam mares.

Ana Luiza Romanielo em "A Trajetória da Personagem no Cinema de Estrada", faz uma análise comparativa entre os conhecidos road movies, filmes de estrada, e o romance de formação de origem alemã, em que a personagem se constitui pelo processo de desenvolvimento, transformação do sujeito. "O gênero costuma apresentar características recorrentes, como a abordagem do deslocamento rumo ao desconhecido, questões de rupturas e subversão" (ROMANIELO, p. 07).

Violeta é uma personagem de formação, suas estradas não são linhas retas, são labirintos, não-lugares. Segundo Augé (2007, p. 87) "quando rodamos na auto-estrada, fazemos compras no supermercado ou esperamos num aeroporto" os não-lugares são sinalizados por textos, informando para onde e como devemos prosseguir. Violeta transita por esses lugares de passagem, os cenários são ruas, praia, hotel, aeroporto. Nesses lugares sinalizados "o viajante fica, de certo modo, dispensado de parar e até mesmo de olhar" (AUGÉ, 2007, p. 88), o que acontece com a personagem que até o momento de encontro com Bel (Gabi Pereira) e Nassir (Thiago Martins) não consegue olhar para 0 outro. Também não olhada, Violeta, encontra-se anônima e solitária na cidade-praia; praia-cidade.

O primeiro contato traumático da personagem de estrada com a cidade se dá nas pedaladas de Violeta, que se movimenta por ruas agitadas, depois por uma rua menos habitada, as ruas de bairros, em que leva o primeiro tombo e externaliza o primeiro machucado. Chega a uma obra barulhenta, questiona uma conhecida, quer respostas, que não estão nela e em nenhum lugar: "- Ele esperou, entendeu. Agora você tem o apartamento que você sempre sonhou. - Ele esperou o 
ISSN 2237-9126

que? Comprar um apartamento? Ele esperou a gente ter um apartamento pra fazer isso comigo? É isso? Ele esperou um apartamento, pra deixar um recado no celular? Comprar um apartamento? Ele esperou a gente ter um apartamento pra fazer isso comigo, pra se separar de mim, é isso?".

No diálogo, o apartamento é o protagonista, não é o mar que importa, é o concreto, a resposta concreta que não tem vida na voz de ninguém, apartamentos não falam - o barulho vem do mar que no ritmo das ondas pode tranquilizar como uma canção, mas também pode causar imensas destruições.

A conversa se dá em uma construção, há operários trabalhando, barulho de máquinas e concreto sendo edificado (Figura 3). Violeta vai para uma sala vazia, a vemos caminhando, prestes a explodir, sentimento indicado pelo extintor no enclausuramento do corredor (Figura 4). Ela entra e sai deste corredor, acaba por encontrar uma porta que se abre para uma paisagem natural, mas ao adentrar esse lugar tropeça em arames, vestígios das edificações que são construídas ao lado. A civilização invade a paisagem natural, o que externaliza mais machucados na personagem e a deixa apequenada no cenário natural (Figura 5), em que não se busca respostas, mas a emoção, ela encolhe-se, como Gaston Bachelard (1978) indica necessário, para que o canto no mundo possa ser habitado. 
VAZ, Aline. As paisagens do filme $O$ Abismo Prateado (Karim Aïnourz). Domínios da Imagem, Londrina, v. 10, n. 19, p. 156-171, jul./dez. 2016.

ISSN 2237-9126

\section{Figura 3 - Frame do filme O Abismo Prateado}

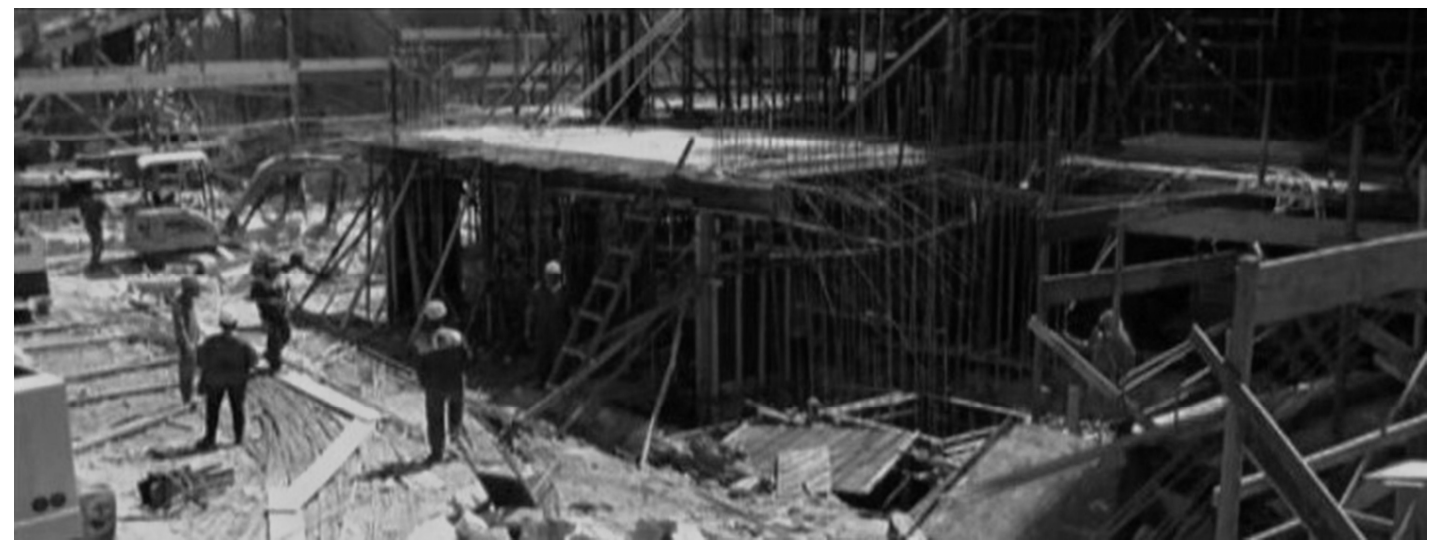

O caos arquitetônico.

Figura 4 - Frame do filme O Abismo Prateado

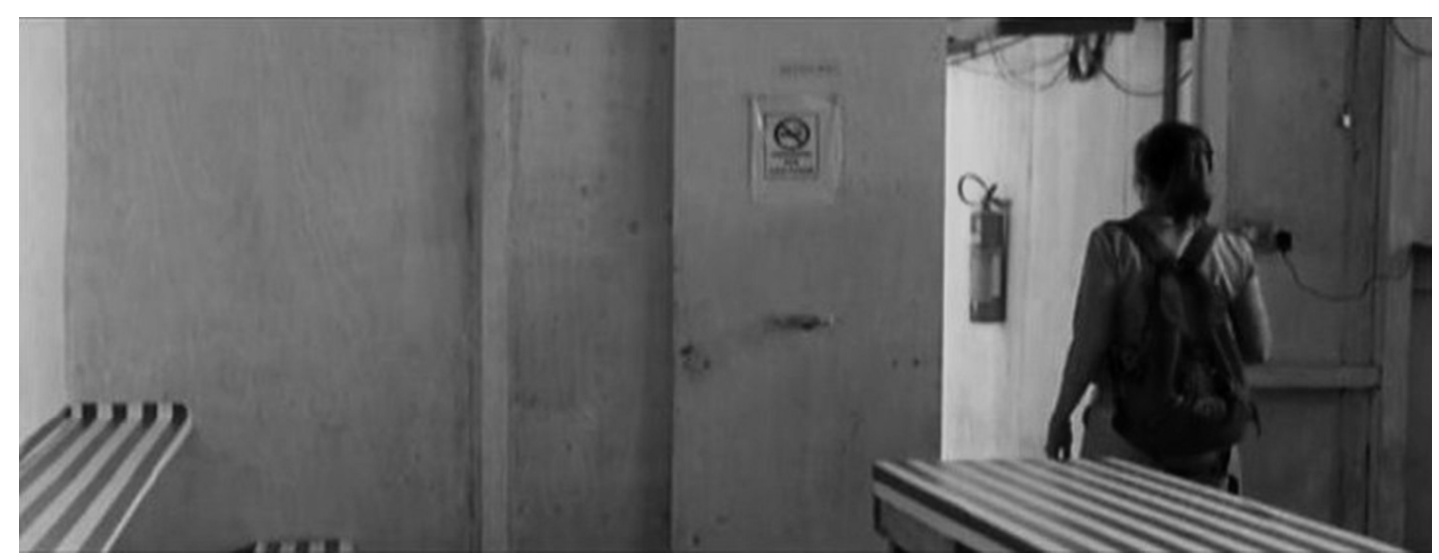

Violeta prestes a explodir no enclausuramento. 
VAZ, Aline. As paisagens do filme $O$ Abismo Prateado (Karim Aïnourz). Domínios da Imagem, Londrina, v. 10, n. 19, p. 156-171, jul./dez. 2016.

ISSN 2237-9126

\section{Figura 5 - Frame do filme O Abismo Prateado}

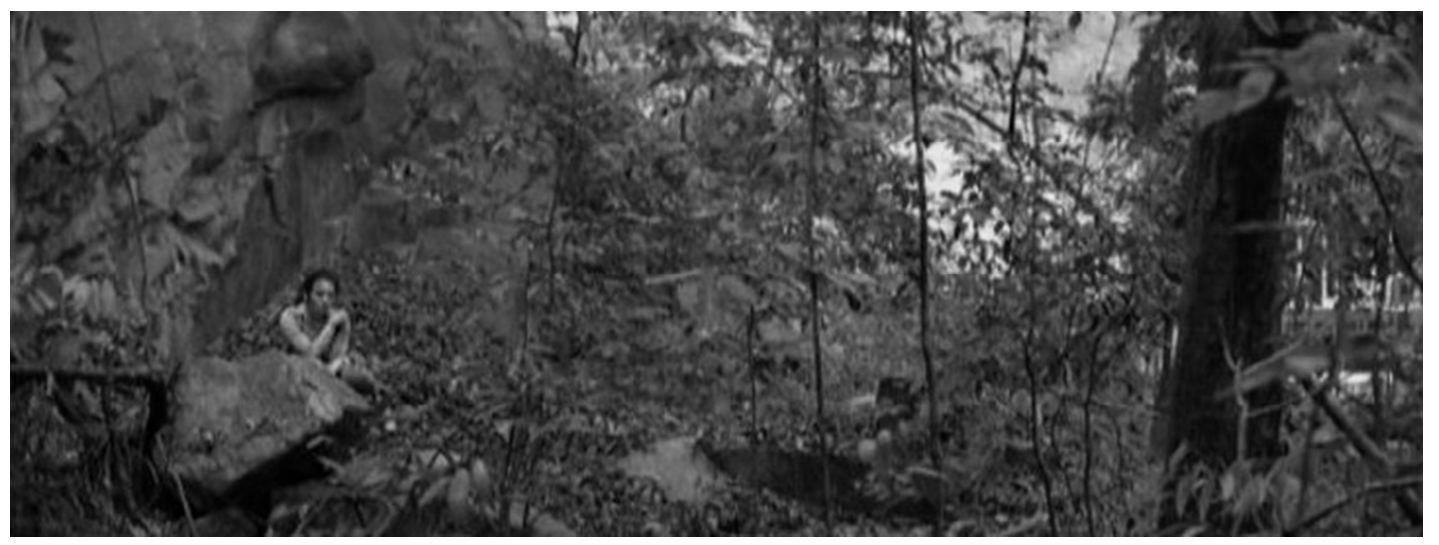

Violeta apequenada na natureza, em busca de um encolhimento no canto do mundo.

Quando volta para casa, Violeta limpa os machucados, sai na varanda, o rosto assemelha-se ao sentimento de estar perdida e, então, contempla a cidade. Por meio do olhar da personagem olhamos para a cidade que nos olha. Aparentemente, o ambiente segue sua normalidade, o concreto e o mar permanecem inalterados, mas a personagem não se vê mais refletida nesse espaço - prega um espelho na pare de do banheiro, tenta olhar para si mesma.

Em um momento de compreensão do que aconteceu e não do porque aconteceu, após um período de contemplação da cidade, em que há o concreto e o mar (Figura 6), Violeta joga-se na cidade, o abismo é invadido, inicia-se a busca pelo marido que será a busca por si mesma, em meio à fuga para longe, o medo do futuro ausente e a falta de aceitação do presente que se impõe.

[...] todas as atitudes individuais são concebíveis: a fuga (para casa, para longe), o medo (de si, dos outros), mas também a intensidade da experiência (o desempenho) ou a revolta (contra os valores estabelecidos). Não há mais análise social que possa fazer economia dos indivíduos, nem análise dos indivíduos que possa ignorar os espaços por onde eles transitam (AUGÉ, 2007, p. 109). 
Figura 6 - Frame do filme O Abismo Prateado

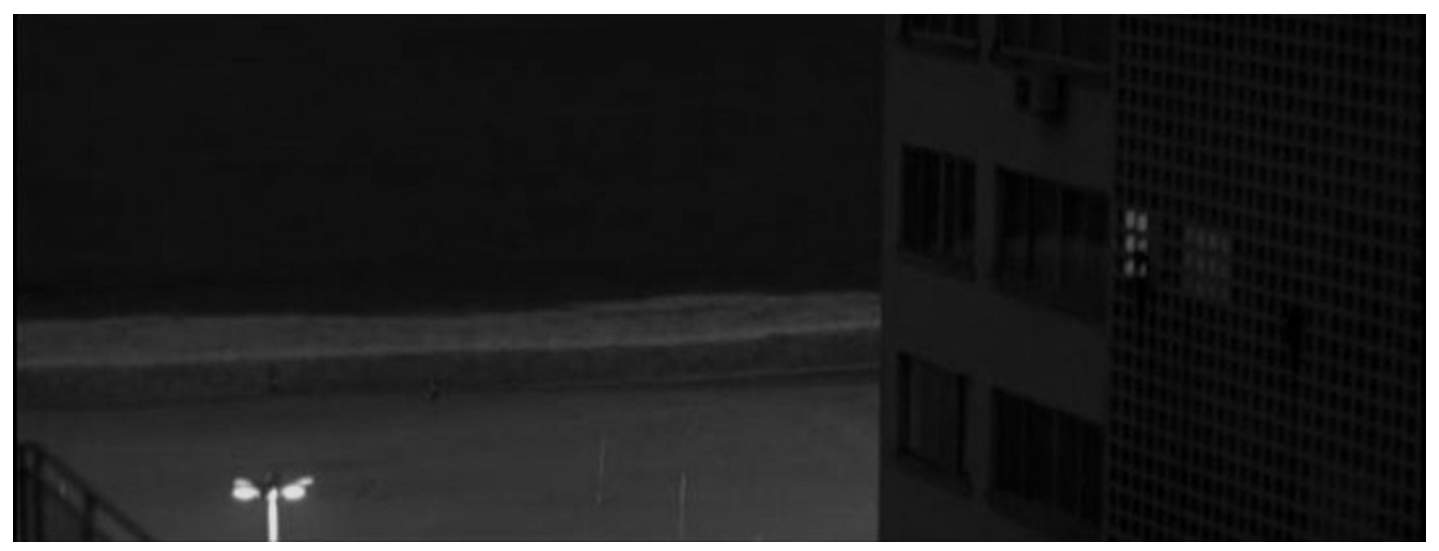

As paisagens do abismo construído entre a natureza e o concreto.

Os espaços de passagem em que Violeta transita são paisagens de contemplação e tensão. Os túneis, as ruas, são escuros e as luzes dos carros tendem a sempre ofuscar o olhar. Em alguns momentos, a protagonista, se coloca em sentido contrário aos carros (Figura 7), justamente quando a luz dos faróis é atirada aos olhos, uma luz que não clareia, mas cega. A personagem não sabe para onde ir, ela está contra o caminho que lhe é ofuscado pelo clarão que deforma a vista.

\section{Figura 7 - Frame do filme O Abismo Prateado}

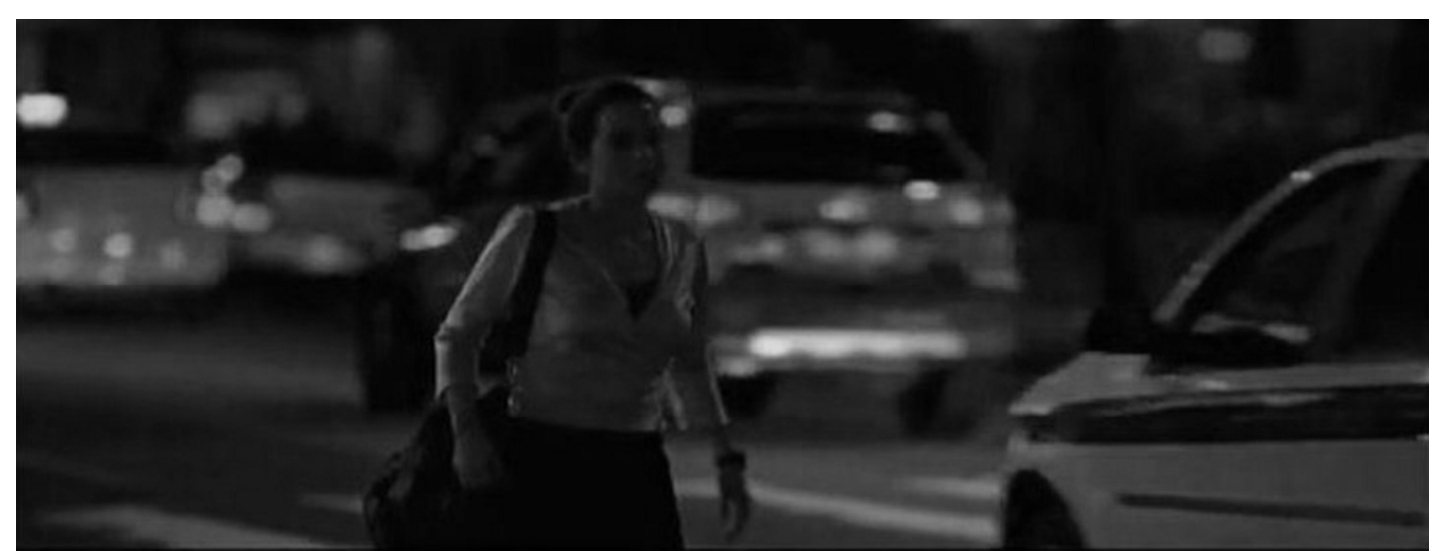

Violeta anda contra os carros, não segue o movimento da cidade. 
VAZ, Aline. As paisagens do filme $O$ Abismo Prateado (Karim Aïnourz). Domínios da Imagem, Londrina, v. 10, n. 19, p. 156-171, jul./dez. 2016.

ISSN 2237-9126

A transformação no olhar de Violeta se dá ao encontrar Bel no banheiro, personagem que está de passagem. Na praia ela reencontra a menina junto ao pai Nassir: no espaço da natureza em que é possível olhar com contemplação ao seu redor. Ela olha para essas duas personagens, que habitam espaços que não estabelecem vínculos, são viajantes. Quando há o retorno do olhar entre as personagens, elas perdem a característica do anonimato, o que provoca um encontro com a própria identidade, o que nos remete ao foco narrativo do romance de formação:

Apesar de o desenvolvimento pessoal constituir o foco desse tipo de narrativa, o aspecto social sempre se fará presente, pois o crescimento se dará a partir da interação com os demais e com 0 ambiente no qual o protagonista está inserido. Mais do que isso: o indivíduo necessita da sociedade e não do isolamento para se desenvolver (ROMANIELO, 2013, p. 11).

Violeta, então, presa no não-lugar - no trajeto da cidade - visita o aeroporto com as personagens de passagem. Há uma barreira, uma vidraça que dá a falsa noção de proximidade com o avião, mas não as permite alcançá-lo, não as permite fugir do ser e estar encolhidas em si mesmas (Figura 8).

\section{Figura 8 - Frame do filme O Abismo Prateado}

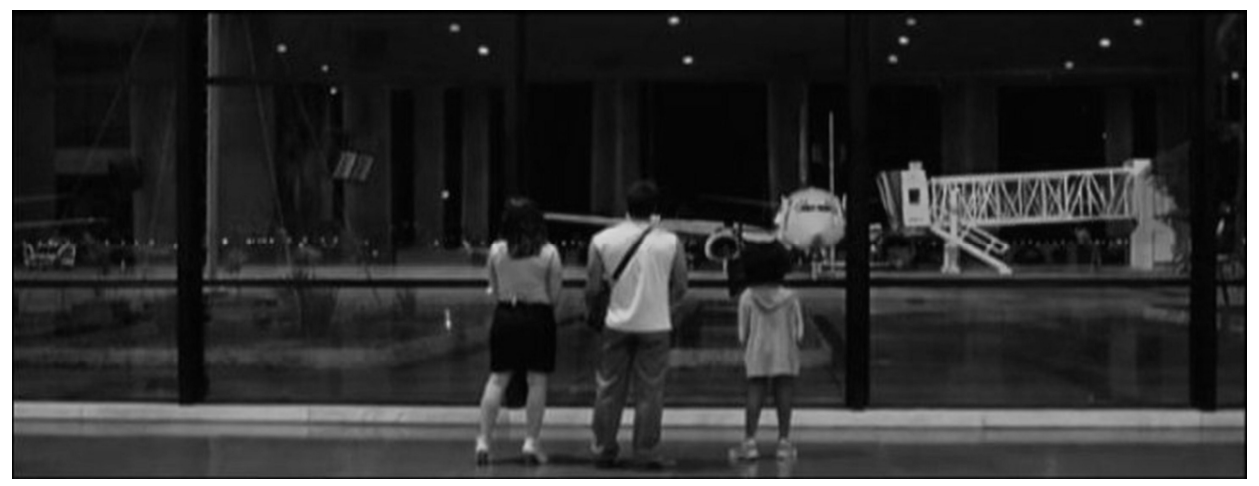

O não-lugar e a impossibilidade de voar. 

da Imagem, Londrina, v. 10, n. 19, p. 156-171, jul./dez. 2016.

ISSN 2237-9126

Após reconhecerem a barreira que o não-lugar (aeroporto) impõe, as personagens viajantes, o pai e a filha, continuam o caminho. Elas saem da vida de Violeta, esta que volta para casa, caminha pelo calçadão e - ao som de Olhos nos Olhos de Chico Buarque, interpretada por Bárbara Eugenia -, atravessa a rua, a ligação entre a praia e os edifícios. Encerra-se a viagem da personagem de estrada em que "conflitos internos ou familiares, a necessidade de fuga, a promessa de um encontro funcionam como motivadores iniciáticos, porém o foco do road movie estará sempre nos acontecimentos do percurso e nas mudanças advindas desses incidentes (ROMANIELO, p. 19). Ao olhar e ser olhada para e pelo outro, Violeta, encontra a própria essência nos termos de Martin Heiddeger (1979), podendo assim "compreender" e "possuir" o mundo. A protagonista agora habita o seu canto no mundo, ela volta para a sua casa, que pode ser a casa de Bachelard (1978), aquela que evoca sonhos e que o sonhar constrói um indício de futuro, assim como pressupõe a música de Chico Buarque que prenuncia uma superação afetiva.

Ainda, vivenciando a experiência do não-lugar, deixamos Violeta e partimos em uma nova viagem, seguimos com Nassir e Bel (Figura 9). Cumprimos nossa passagem de espectador. No movimento da estrada, a câmera "reforça a impressão de que há um mundo do lado de lá, que existe independentemente da câmera em continuidade ao espaço da imagem percebida" (XAVIER, 2005, p. 22), existem outras e novas histórias além de Violeta. 


\section{Figura 9 - Frame do filme O Abismo Prateado}

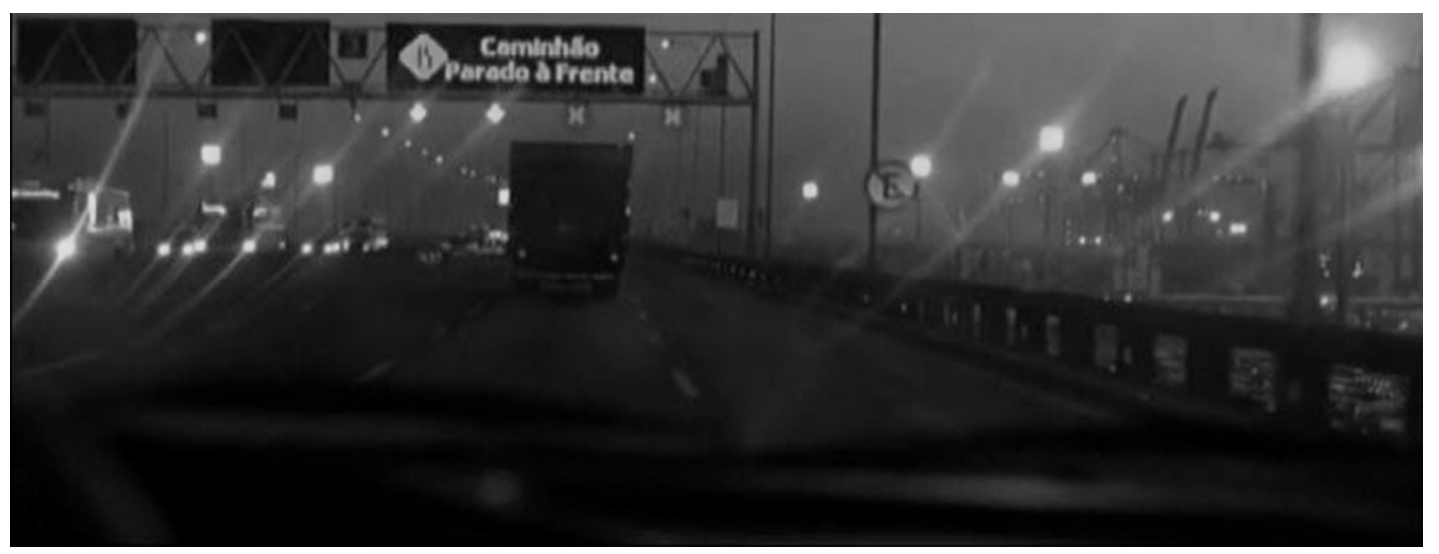

O cumprimento do contrato de passagem com o não-lugar.

\section{Considerações Finais}

André Bazin (1989) em "A evolução da linguagem cinematográfica" observa como tudo aquilo que observamos na tela do cinema pode acrescentar à representação da coisa na tela. No filme $O$ Abismo Prateado (Karim Aïnouz; 2013) percebe-se a representação de uma praia invadida pela intervenção urbana, em que as personagens compõem um híbrido entre o racional e a emoção, cultuado no labirinto que se funde o lugar do morar. O lugar de contemplação, que a praia deveria ocupar, parece representar o caos no olhar de uma paisagem que ressignifica o lugar fixo, mas não se comunica com o espaço aberto entre o sujeito e o habitar, formando o abismo do não-lugar.

Djalma parece deslocado dentro da cidade - pequena demais para o homem que precisa de ar -, a personagem mergulha no mar, mas é sufocada pela composição de paisagens urbanas ambientadas no espaço contemplativo da praia. Violeta tenta sair do labirinto que se forma no olhar deformado pelo trauma do abandono, vive dentro de um abismo entre o concreto dos edifícios, das estradas - que (tem um espaço a mais aqui) não guiam caminhos -, do mar que não permite 
VAZ, Aline. As paisagens do filme O Abismo Prateado (Karim Aïnourz). Domínios da Imagem, Londrina, v. 10, n. 19, p. 156-171, jul./dez. 2016.

ISSN 2237-9126

navegações e desempenha significado decorativo para os habitantes com olhares desatentos - que não vivenciam as experiências do espaço como área de lazer e sim de passagem.

Nassir e Bel cumprem o contrato de passagem com o não-lugar que "constrói uma relação fictícia entre olhar e paisagem" (AUGÉ, 2007, p. 79). As personagens, pai e filha, podem estabelecer uma relação de contemplação com a paisagem, já que estão de passagem e não pertencem ao lugar pelo qual passeiam. No fim da narrativa é com elas que vamos embora, pois nossa vivência é daquele que experimenta $o$ espaço como espectador. Somos viajantes pelo espaço cinematográfico - que nos termos de Augé (2007, p. 79) o "espaço do viajante seria, assim, o arquétipo do não-lugar":

Por intermédio dos pressupostos analisados até aqui, percebe-se que os lugares, representados pelos enquadramentos do cinema, são possuídos por seus passantes, personagens e espectador que transformam o espaço do cinema pela significação do olhar que flana pela tela.

\section{Referências}

AUGÉ, Marc. Não-lugares. Papirus Editora, 2007.

ARAÚJO, Maria Christina B. et al. Análise da ocupação urbana das praias de Pernambuco, Brasil. Revista de Gestão Costeira Integrada, v. 7, n. 2, 2007. p. 97-104.

BAZIN, André. A evolução da linguagem cinematográfica. In O cinema, São Paulo: Brasiliense, 1989. p. 66-68.

BACHELARD, Gaston. Os pensadores. São Paulo: Abril Cultural, 1978.

BAUMAN, Zygmunt. Confiança e medo na cidade. Rio de Janeiro: Zahar, 2009.

BOURDIEU, Pierre. Remarques provisoires sur la perception sociale du corps. Paris, v. 14, 1977. 
COSTA, MF da et al. Verticalização da Praia da Boa Viagem (Recife, Pernambuco) e suas consequências sócio-ambientais. Revista da Gestão Costeira Integrada. Vale do Itajaí, v. 8, n. 2, 2008. p. 233-245.

DIDI-HUBERMAN, Georges. O que vemos, o que nos olha. São Paulo: Editora 34, 1998.

HALL, Stuart. A identidade cultural na pós-modernidade. Rio de Janeiro: TupyKurumin, 2006.

HEIDEGGER, Martin. Conferências e Escritos Filosóficos. Tradução e notas Ernildo Stein. São Paulo: Abril Cultural, 1979.

LAMPERT, Letícia. Conhecidos de vista: a cidade revelada através de olhares, janelas e fotografias. Dissertação (Mestrado em Artes Visuais). Porto Alegre: 2013.

LEMOS, André. Cidade-ciborgue: a cidade na cibercultura. Galáxia, v. 4, n. 8, 2007. p. 129-148.

MACHADO, Helena. A construção social da praia. In: Sociedade e Cultura 1. Braga: Universidade do Minho, 2000. p. 201-218.

ROMANIELO, Ana Luiza. A trajetória da personagem no cinema de estrada. Revista Memento. Minas Gerais, 2013. p. 154-167.

XAVIER, Ismail. A janela do cinema e a identificação. In $O$ discurso cinematográfico. Rio: Paz e Terra, 2005. p. 17.

\section{FILMOGRAFIA}

O ABISMO prateado. Direção de Karim Aïnouz. Brasil: 2013. (83min).

O SOM ao redor. Direção de Kleber Mendonça Filho. Brasil: 2012. (131 min). 